\title{
INFLUENCE OF ORGANIC AND INORGANIC FERTILIZERS ON GROWTH, YIELD AND PHYSIO-CHEMICAL PROPERTIES OF PAPAYA
}

\author{
S. Easmin ${ }^{1}$, M. A. Hoque ${ }^{1}$, M. M. H. Saikat ${ }^{2}$ and E. Kayesh ${ }^{1 *}$
}

\begin{abstract}
A field experiment was conducted to investigate the effect of organic and inorganic fertilizers on growth, yield and physio-chemical properties of papaya (Carica papaya) from February to December 2019. The experiment was designed into twelve treatments $\left[\mathrm{T}_{1}=\right.$ Control, $\mathrm{T}_{2}=100 \%$ RDF (Recommended Dose of Fertilizers), $\mathrm{T}_{3}=50 \% \mathrm{RDF}+$ $50 \%$ MOC (Mustard Oil Cake), $\mathrm{T}_{4}=50 \% \mathrm{RDF}+50 \%$ VER (Vermicompost), $\mathrm{T}_{5}=50 \%$ $\mathrm{RDF}+50 \% \mathrm{PM}$ (Poultry Manure), $\mathrm{T}_{6}=25 \% \mathrm{RDF}+75 \% \mathrm{MOC}, \mathrm{T}_{7}=25 \% \mathrm{RDF}+75 \%$ VER, $\mathrm{T}_{8}=25 \% \mathrm{RDF}+75 \% \mathrm{PM}, \mathrm{T}_{9}=100 \% \mathrm{MOC}, \mathrm{T}_{10}=100 \% \mathrm{VER}, \mathrm{T}_{11}=100 \% \mathrm{PM}$ and $\left.\mathrm{T}_{12}=\mathrm{MOC}+\mathrm{VER}+\mathrm{PM}\right]$ at the experimental field of Department of Horticulture, Bangabandhu Sheikh Mujibur Rahman Agricultural University, Gazipur. The experiment was laid out in randomized complete block design with three replications. The effect of treatments varied significantly for most of the characters studied. Results showed that the plant growth, yield contributing traits, fruit yield and quality of papaya significantly increased in $\mathrm{T}_{10}$ treatment compared to other treatments. The maximum amount of dry matter of fruit $(4.37 \%)$, TSS $(18.17 \%)$, total sugar $(9.43 \mathrm{~g} / 100 \mathrm{~g})$, reducing sugar $(6.34 \mathrm{~g} / 100 \mathrm{~g}), \beta$ - carotene $(0.24 \mathrm{mg} / 100 \mathrm{~g})$, mineral as $\mathrm{Ca}(0.39 \%), \mathrm{Mg}(0.33 \%)$ and $\mathrm{K}(2.08 \%)$ were found in $\mathrm{T}_{10}$ treatment and the minimum amount were found in the control $\mathrm{T}_{1}$. The maximum amount of non-reducing sugar was obtained from $\mathrm{T}_{12}(3.93$ $\mathrm{g} / 100 \mathrm{~g})$ and the minimum from $\mathrm{T}_{3}(2.23 \mathrm{~g} / 100 \mathrm{~g})$. Ascorbic acid was found maximum in $\mathrm{T}_{7}(24.99 \mathrm{mg} / 100 \mathrm{~g})$ and minimum from $\mathrm{T}_{11}(22.00 \mathrm{mg} / 100 \mathrm{~g})$. A significant influence of $\mathrm{T}_{10}$ treatment on growth, yield and physio-chemical characters was observed. The application of $100 \%$ vermicompost which influenced growth, yield and physio-chemical properties of papaya in Salna series of Red Brown-terrace soil is suggested.
\end{abstract}

Keywords: Mustard oil cake, vermicompost, yield traits, $\beta$ - carotene, ascorbic acid, sugar content, Carica papaya $\mathrm{L}$.

\section{INTRODUCTION}

Papaya (Carica papaya L.) is one of the most nutritious and delicious fruits in the world. It is essentially a tropical fruit and commercially grown in tropical and sub-tropical areas (Yadava et al., 1990). It is believed to be originated in Mexico and spread to almost all the corners of the tropical world. It is a good source of protein, carbohydrate, fiber, vitamin $\mathrm{A}$ and $\mathrm{C}$, carotene and mineral like iron, phosphorous and potassium (Mamta et al., 2017). Papaya is primarily a fresh-market fruit, and is used in drinks, jams, pectin, candies and as crystalized fruit. Green fruit may be cooked

\footnotetext{
${ }^{1}$ Department of Horticulture, Bangabandhu Sheikh Mujibur Rahman Agricultural University, Gazipur 1706, Bangladesh. ${ }^{2}$ Department of Genetics and Plant Breeding, Bangabandhu Sheikh Mujibur Rahman Agricultural University, Gazipur 1706, Bangladesh.*Corresponding author: ekayeshhrt@bsmrau.edu.bd
} 
as a vegetable. Traditionally leaves have been used for treatment of a wide range of ailments, like in the treatment of malaria, dengue, jaundice, immune modulatory and antiviral activity (Singh et al., 2020). It has several well-known industrial uses, notably for the enzyme pepsin (EI Moussaoui et al., 2001) which has properties similar to gastric pepsin. In Bangladesh, it is one of the leading fruits and the yield of papaya is far below compared to other countries of the world (Chowdhury et al., 2008). Singh et al. (2012) noted that productivity of papaya is low because of the lack of appropriate nutrient management. Papaya bears flowers and fruits round the year, all the area papaya are increasing and limited information is available on organic production system in this crop (Reddy et al., 2010). It is nutrient exhaustive and fertilizer responsive crop. Both organic and inorganic fertilizers have potential role on the growth yield of papaya. But indiscriminate use of inorganic fertilizers changes physical, chemical and biological properties of soil and creates problem to the environment and health hazard due to toxic residual effects. Some of them included increased outbreak of pests and diseases including weeds; affecting the productivity. On the other hand organic fertilizers such as cow dung, vermicompost, poultry manure, FYM and mustard oil cake help in improving soil texture, structure, water holding capacity, aeration and microbial activities of soil (El-Shakweer et al., 1998). A number of studies pointed out to the fact that organic farming approaches offered the most sustainable way of crop production besides contributing to environmental protection through minimizing degradation (Ojeniyi, 2000; Maritus and Vleic, 2001).
Further, the organically raised crops besides being nutritious and also eliminated the risk of pesticide residues to the consumers, thus ensuring food safety. Moreover, organically produce product demand is increasing day by day. In view of this, there is needed to be increase production of papaya by organic way. Therefore, the present study was aimed to find out the organic and inorganic fertilizer effects on growth, yield and physio-chemical properties of papaya and also standardize the doses for maximizing yield of papaya.

\section{Materials and Methods}

The experiment was conducted at research field and Laboratory of the Department of Horticulture, Bangabandhu Sheikh Mujibur Rahman Agricultural University, Gazipur, during the period from February to December 2019. The site was about $24.09^{\circ} \mathrm{N}$ latitude and $90.26^{\circ} \mathrm{E}$ longitude and at an elevation of 8.40 $\mathrm{m}$ from the sea level.

\section{Experimental materials and land preparation}

Papaya seedlings (Red lady) were collected from BRAC nursery, Gazipur. The experiment was carried out twelve treatments in a Randomized Complete Block Design (RCBD) with four replications. In each treatment consisted of 8 plants and one replication had 24 plants. The experimental field was 2-3 plough with fine tilth. Pits of $30 \times 30 \times 30 \mathrm{~cm}$ were prepared and planting two seedlings of papaya in each pit with the spacing of row to row $2 \mathrm{~m}$ and plant to plant 2 $\mathrm{m}$. After at a flowering stage one tree has been cut down from each treatment. Intercultural operation such as weeding, gap filling, staking 
and irrigation was done when needed. Dried leaves of plants were removed to keep field disease free.

\section{Treatments of the experiment}

T1: Control

$\mathbf{T}_{\mathbf{2}}$ : $100 \%$ Recommended dose of fertilizer (225: 100: $225 \mathrm{~g} \mathrm{~N}-\mathrm{P}_{2} \mathrm{O}_{5}-\mathrm{K}_{2} \mathrm{O}$ per plant) follow the Fertilizer Recommendation Guide (BARC, 2012)

T $_{3}$ : $50 \%$ Recommended dose $+50 \%$ Mustard Oil Cake $(2.25 \mathrm{~kg} /$ plant $)$

T4: $50 \%$ Recommended dose $+50 \%$ Vermicompost $(6.25 \mathrm{~kg} /$ plant $)$

T5: $50 \%$ Recommended dose $+50 \%$ Poultry Manure $(9.25 \mathrm{~kg} /$ plant $)$

T6: $25 \%$ Recommended dose $+75 \%$ Mustard Oil Cake (3.8 kg/ plant)

T7: $25 \%$ Recommended dose $+75 \%$ Vermicompost $(9.4 \mathrm{~kg} /$ plant)

Ts: $25 \%$ Recommended dose $+75 \%$ Poultry Manure (13.8 kg/ plant)

T9: $100 \%$ Mustard Oil Cake (4.5 kg/ plant) (BARC, 2012)

T10: $100 \%$ Vermicompost (12.5 kg/ plant) (BARC, 2012)

T11: $100 \%$ Poultry Manure $(18.5 \mathrm{~kg} /$ plant $)$ (BARC, 2012)

T12: Mustard Oil Cake (1.5 kg/ plant) + Vermicompost $(4 \mathrm{~kg} /$ plant $)+$ Poultry Manure (6 $\mathrm{kg} / \mathrm{plant})$

\section{Application of treatments}

Allorganics were applied on Nequivalentbasis. Calculated quantities of inorganic fertilizers and half of total organic fertilizers were applied at the time of planting. Recommended dose of nitrogen and potassium inorganic fertilizers and remaining half of organics were applied in four splits at an interval of 30 days starting from 30 days after transplanting till flowering by ring method (30 $\mathrm{cm}$ away from plant on around side of plant), entire dose of phosphorus and boron was applied at the time of planting as basal dose (BARC, 2012).

\section{Data collection}

Growth, yield and physio- chemical data were collected at different growing period. Growth parameters such as the Plant height $(\mathrm{cm})$ was measured with a measuring scale. The plant diameter $(\mathrm{cm})$ was measured with a measuring tape. Number of leaves/plant were manually counted. Leaf area $\left(\mathrm{cm}^{2}\right)$ was measured by non-destructive method followed by Khan el. al. (2016). Petiole length $(\mathrm{cm})$ and canopy $(\mathrm{cm})$ was measured with measurement scale.

Yield parameters as days to flowering initiation, number of flowers/plant, days to fruit setting, number of fruits/plant, fruit length $(\mathrm{cm})$ and fruit diameter $(\mathrm{cm})$ was measured with the help of verniar calipers. The fresh fruit weight (g) was taken immediately after harvesting with the help of electronic balance. The five randomly fruits selected were cut open longitudinally and measured the pulp thickness (cm) with the help of vernier calipers. Dry matter (\%) was measured by oven dried fruit weight was taken with the help of electronic balance and express in percentage. yield/plant (kg/plant), yield/ha (MT/ha) were recorded. Physio-chemical parameters such as such as TSS (\%) was estimated by hand refractometer (Model: Atago N1, Japan). Total sugar $(\mathrm{g} / 100 \mathrm{~g})$, reducing sugar $(\mathrm{g} / 100 \mathrm{~g})$ and nonreducing sugar $(\mathrm{g} / 100 \mathrm{~g})$ were estimated as per 
the procedure by Somogyi (1952). Ascorbic acid (mg/100g) was estimated by using AOAC, 1965 method. $\beta$-carotene (mg/100g) was measured by spectrophotometer (Model no. 200-20, Hitachi, Japan) at 663 ๆm, $645 \eta \mathrm{m}, 505 \eta \mathrm{m}$ and $453 \eta \mathrm{m}$ (Nagata and Yamashita, 1992). Calcium (\%), magnesium $(\%)$ and potassium (\%) were measured by vanadomolybdate method through the Atomic Absorption Spectrophotometer (Model 17030, Hitachi, Japan) at a wavelength of 442.8 $\eta \mathrm{m}, 285.5 \eta \mathrm{m}$ and $766.5 \eta \mathrm{m}$, respectively.

\section{Initial and after harvest soil analysis}

Soil nutrient status was estimated before planting and after harvesting. Total nitrogen of soil was determined by micro-kjeldahl method. Total $\mathrm{P}$ and $\mathrm{K}$ content of soil sample was determined by using Vanadomolybdate method.
Table 1. Physio-chemical properties of the soil at the experimental plot before planting

\begin{tabular}{lc}
\hline Soil properties & Analytical data \\
\hline Soil pH & 5.8 \\
Available N (\%) & 0.06 \\
Available P (\%) & 6.13 \\
Available $\mathrm{P}_{\mathrm{K}}(\%)$ & 0.61 \\
\hline
\end{tabular}

\section{Statistical analysis}

The mean was estimated using the statistix-10 computer program. Analysis of variance was performed for all the characters to test the differences between the means of the effect of effect of the treatments. Treatment means were analyzed by Duncan's Multiple Range Test (DMRT). Mean and Co-efficient of variation ( $\mathrm{CV} \%)$ were also estimated using the statistix-10 computer program.

Table 2. Physio-chemical properties of the soil at the experimental plot after harvesting

\begin{tabular}{lccc}
\hline Treatments & Nitrogen (\%) & Phosphorous (\%) & Potassium (\%) \\
\hline $\mathrm{T}_{1}=$ Control & 0.02 & 3.39 & 0.12 \\
$\mathrm{~T}_{2}=100 \% \mathrm{RDF}$ & 0.06 & 5.51 & 0.64 \\
$\mathrm{~T}_{3}=50 \% \mathrm{RDF}+50 \% \mathrm{MOC}$ & 0.05 & 5.68 & 0.60 \\
$\mathrm{~T}_{4}=50 \% \mathrm{RDF}+50 \% \mathrm{VER}$ & 0.03 & 6.13 & 0.59 \\
$\mathrm{~T}_{5}=50 \% \mathrm{RDF}+50 \% \mathrm{PM}$ & 0.08 & 6.20 & 0.67 \\
$\mathrm{~T}_{6}=25 \% \mathrm{RDF}+75 \% \mathrm{MOC}$ & 0.09 & 6.69 & 0.73 \\
$\mathrm{~T}_{7}=25 \% \mathrm{RDF}+75 \% \mathrm{VER}$ & 0.06 & 6.36 & 0.69 \\
$\mathrm{~T}_{8}=25 \% \mathrm{RDF}+75 \% \mathrm{PM}$ & 0.07 & 4.16 & 0.60 \\
$\mathrm{~T}_{9}=100 \% \mathrm{MOC}$ & 0.08 & 6.67 & 0.63 \\
$\mathrm{~T}_{10}=100 \% \mathrm{VER}$ & 0.06 & 6.10 & 0.62 \\
$\mathrm{~T}_{11}=100 \% \mathrm{PM}$ & 0.07 & 6.00 & 0.60 \\
$\mathrm{~T}_{12}=$ MOC + VER + PM & 0.05 & 6.23 & 0.61 \\
\hline
\end{tabular}

$\mathrm{RDF}=$ Recommended dose of fertilizer; $\mathrm{VER}=$ Vermicompost; $\mathrm{MOL}=$ Mustard oil cake; $\mathrm{PM}=$ Poultry manure. 


\section{Results and Discussion}

\section{Plant height}

The plant height was recorded at the time of first harvesting (Table 1). The tallest plant height was recorded from $T_{10}(143.67 \mathrm{~cm})$ treatment which was statistically identical to $\mathrm{T}_{12}(141.67 \mathrm{~cm})$ treatment. The lowest plant height was recorded in the control treatment $T_{1}$ $(101.67 \mathrm{~cm})$ which was significantly different from all other treatments. Vermicompost treated plant generated the maximum height of the papaya plant through better uptake of minerals and microelements. It has high microbial activity due to presence of fungi, bacteria and actinomycetes which can produce plant growth regulators (PGRs) (Tomati et al., 1988). Similar findings was found from Sindoni et al. (2009) in papaya and Joshi and Vig (2010) in tomato.

\section{Plant diameter}

The study revealed that there was a highly significant effect of organic and inorganic sources of nutrients on plant diameter of papaya (Table 1). The maximum plant diameter was observed from $\mathrm{T}_{10}(53.67 \mathrm{~cm})$ and the minimum was obtained from $\mathrm{T}_{1}(40.67$ $\mathrm{cm})$ treatment which was statistically similar to $\mathrm{T}_{3}(42.33 \mathrm{~cm})$ and $\mathrm{T}_{5}(42.33 \mathrm{~cm})$ treatment. According to Reddy et al. (2013) reported that the diameter of the stem was found maximum due to getting optimum nutrients at an early growing stage. This finding was well supported with the finding of Akinyemi and Akande (2008) who observed maximum stem diameter of papaya plant due to the application of vermicompost with or without any combination of other fertilizers.

\section{Number of leaves per plant}

Leaves number was influenced by different levels of organic and inorganic fertilizers (Table 1). There was a gradual rising trend of leaf number at different days after planting. The maximum number of leaves was observed from $\mathrm{T}_{10}(27.67)$ which was statistically similar to $\mathrm{T}_{12}(26.33)$ treatment. The minimum number of leaves was observed in the control treatment $\mathrm{T}_{1}$ (15.33). This finding was well supported with the finding of Krishna et al. (2018) who observed the application of vermicompost or vermicompost in combination with other organic fertilizers increased the number of leaves of the papaya plant.

\section{Leaf area}

Leaf area showed significant variation in response to different organic and inorganic fertilizers at a variation time point after planting (Table 1). The maximum leaf area was also measured in $\mathrm{T}_{10}\left(1334.70 \mathrm{~cm}^{2}\right)$ treatment which was statistically alike with $\mathrm{T}_{12}(1333.30$ $\left.\mathrm{cm}^{2}\right)$ treatment. The minimum leaf area was measured in the control $\mathrm{T}_{1}\left(1319.30 \mathrm{~cm}^{2}\right)$ which was statistically dissimilar from all other treatment. Singh et al. (2008) reported that the leaf area of strawberry plant increase due to the application of Vermicompost combination with other fertilizers and improve soil characteristics. These results are in conformity with the findings reported by Yadav et al. (2011a) in papaya.

\section{Petiole length}

The length of leaf petiole under the influence of differential treatments varied between $30.67 \mathrm{~cm}$ and $46.67 \mathrm{~cm}$ (Table 1). The highest length was measured in $\mathrm{T}_{10}(46.67 \mathrm{~cm})$ which was statistically similar to $T_{12}(45.33$ $\mathrm{cm})$. The lowest length was measured in the 
Table 1. Influence of organic and inorganic fertilizers on morphological characters of papaya plant

\begin{tabular}{lcccccc}
\hline Treatments & $\begin{array}{c}\text { Plant height } \\
(\mathrm{cm})\end{array}$ & $\begin{array}{c}\text { Plant diameter } \\
(\mathrm{cm})\end{array}$ & $\begin{array}{c}\text { Number of } \\
\text { leaves } / \mathrm{plant}\end{array}$ & $\begin{array}{c}\text { Leaf area } \\
\left(\mathrm{cm}^{2}\right)\end{array}$ & $\begin{array}{c}\text { Petiole } \\
\text { length }(\mathrm{cm})\end{array}$ & $\begin{array}{c}\text { Canopy } \\
(\mathrm{cm})\end{array}$ \\
\hline $\mathrm{T}_{1}=$ Control & $101.67 \mathrm{~g}$ & $40.67 \mathrm{f}$ & $15.33 \mathrm{~g}$ & $1319.3 \mathrm{~h}$ & $30.67 \mathrm{~g}$ & $92.67 \mathrm{~h}$ \\
$\mathrm{~T}_{2}=100 \% \mathrm{RDF}$ & $138.67 \mathrm{c}$ & $50.00 \mathrm{~b}$ & $24.33 \mathrm{c}$ & $1329.3 \mathrm{c}$ & $39.67 \mathrm{~d}$ & $111.00 \mathrm{~b}$ \\
$\mathrm{~T}_{3}=50 \% \mathrm{RDF}+50 \% \mathrm{MOC}$ & $131.00 \mathrm{f}$ & $42.33 \mathrm{ef}$ & $19.67 \mathrm{f}$ & $1325.3 \mathrm{e}$ & $38.67 \mathrm{de}$ & $102.67 \mathrm{~g}$ \\
$\mathrm{~T}_{4}=50 \% \mathrm{RDF}+50 \% \mathrm{VER}$ & $138.00 \mathrm{c}$ & $44.00 \mathrm{de}$ & $21.33 \mathrm{de}$ & $1328.7 \mathrm{~cd}$ & $40.00 \mathrm{~d}$ & $108.00 \mathrm{~cd}$ \\
$\mathrm{~T}_{5}=50 \% \mathrm{RDF}+50 \% \mathrm{PM}$ & $138.00 \mathrm{c}$ & $42.33 \mathrm{ef}$ & $22.00 \mathrm{de}$ & $1323.3 \mathrm{f}$ & $32.33 \mathrm{fg}$ & $103.33 \mathrm{~g}$ \\
$\mathrm{~T}_{6}=25 \% \mathrm{RDF}+75 \% \mathrm{MOC}$ & $134.67 \mathrm{e}$ & $44.00 \mathrm{de}$ & $20.00 \mathrm{ef}$ & $1324.0 \mathrm{ef}$ & $33.67 \mathrm{f}$ & $104.00 \mathrm{fg}$ \\
$\mathrm{T}_{7}=25 \% \mathrm{RDF}+75 \% \mathrm{VER}$ & $137.67 \mathrm{~cd}$ & $47.33 \mathrm{c}$ & $25.67 \mathrm{bc}$ & $1331.3 \mathrm{~b}$ & $43.67 \mathrm{bc}$ & $109.33 \mathrm{bc}$ \\
$\mathrm{T}_{8}=25 \% \mathrm{RDF}+75 \% \mathrm{PM}$ & $135.33 \mathrm{de}$ & $46.67 \mathrm{c}$ & $24.33 \mathrm{c}$ & $1321.7 \mathrm{~g}$ & $42.00 \mathrm{c}$ & $106.67 \mathrm{de}$ \\
$\mathrm{T}_{9}=100 \% \mathrm{MOC}$ & $139.33 \mathrm{bc}$ & $44.33 \mathrm{~d}$ & $19.33 \mathrm{f}$ & $1327.7 \mathrm{~d}$ & $39.33 \mathrm{de}$ & $105.67 \mathrm{ef}$ \\
$\mathrm{T}_{10}=100 \% \mathrm{VER}$ & $143.67 \mathrm{a}$ & $53.67 \mathrm{a}$ & $27.67 \mathrm{a}$ & $1334.7 \mathrm{a}$ & $46.67 \mathrm{a}$ & $113.33 \mathrm{a}$ \\
$\mathrm{T}_{11}=100 \% \mathrm{PM}$ & $140.33 \mathrm{~b}$ & $47.67 \mathrm{c}$ & $25.33 \mathrm{bc}$ & $1324.7 \mathrm{ef}$ & $37.67 \mathrm{e}$ & $107.33 \mathrm{de}$ \\
$\mathrm{T}_{12}=\mathrm{MOC}+\mathrm{VER}+\mathrm{PM}$ & $141.67 \mathrm{ab}$ & $51.33 \mathrm{~b}$ & $26.33 \mathrm{ab}$ & $1333.3 \mathrm{ab}$ & $45.33 \mathrm{ab}$ & $110.33 \mathrm{~b}$ \\
\hline $\mathrm{CV}(\%)$ & 1.03 & 2.34 & 3.96 & 0.06 & 2.79 & 1.00 \\
\hline
\end{tabular}

Means bearing same letter (s) in a column do not differ significantly at $5 \%$ level of probability.

$\mathrm{RDP}=$ Recommended dose of fertilizer; $\mathrm{MOC}=$ Mustard oil cake; VER= Vermicompost; $\mathrm{PM}=$ Poultry manure

control $\mathrm{T}_{1}(30.67 \mathrm{~cm})$ which was statistically similar to $\mathrm{T}_{5}(32.33 \mathrm{~cm})$. These results are in harmony with the findings of Rajamanickam et al. (2008) who stated that the plant treated with vermicompost significantly increase the height, petiole length and other growth parameters of papaya. These present findings also support the findings Sindoni et al. (2009).

\section{Canopy}

Photosynthetic activities largely depend on canopy area which improve the yield and quality of fruit. The maximum canopy was recorded in $T_{10}(113.33 \mathrm{~cm})$ treatment and the minimum canopy was recorded in the control $\mathrm{T}_{1}(92.67 \mathrm{~cm})$. These results are in conformity with the findings reported by Krishna et al. (2018) who stated that the maximum canopy of papaya plants due to the combined application of Vermicompost and biofertilizers along with chemical fertilizers.

\section{Days to flower initiation}

The data presented in Table 2 indicate significant variations in days taken for flowering as influenced by the different doses of organic and inorganic fertilizers. The number of days taken for flowering in papaya plant ranged from 77.67 to 92.33 DAP. In the longest time for flower initiation was recorded in the plant under control $\mathrm{T}_{1}(92.33$ days) and the earliest time for flower initiation was recorded in $\mathrm{T}_{10}$ (77.67 days) treatment. Earliness in flowering due to the higher net assimilation rate on account of slow and horizontal vegetative growth in papaya (Yadav et al., 2011a). These findings are in agreement with the observation of Krishna et al. (2018).

\section{Number of flowers per plant}

Influence of different level of organic and inorganic fertilizers on the number of flowers 
per plant was found significant (Table 2). The maximum number of flowers were observed in $\mathrm{T}_{10}(41.67)$ treatment which was statistically alike with $T_{12}(40.00)$ treatment. The fewest number of flowers was observed in the control $\mathrm{T}_{1}$ (33.33) treatment which was statistically similar to $T_{11}$ (35.00) treatment. These findings are well supported by the findings of Taleshi et al. (2011) who reported that a higher level of vermicompost with nitrogen fertilizers as a potential nutrient source and result in vigorous growth, increase the no. of flower per plant in safflower as compared other nutrient combination.

\section{Days to fruit setting and number of fruits per plant}

Fruits are the ultimate target of crop production. The fruits per plant is one of the most important yield contributing characters in all fruits and as well as papaya. The data depicted in the Table 2 indicate significant variations in the number of days taken for fruiting in the papaya plant. The number of days taken for fruit initiation range from 131.00 to 151.33 . The maximum number of days was noted in the control $\mathrm{T}_{1}$ (151.33) and the minimum was noted from $T_{10}$ (131.00) which was statistically similar to $T_{12}$ (131.67) treatment. The maximum number of fruits per plant was observed in treatment $T_{10}$ (32.67) which was statistically similar to $T_{12}$ (31.67) treatment. The minimum number of fruits per plant was found in $T_{1}$ (23.33) which was statistically similar to $\mathrm{T}_{3}(26.00), \mathrm{T}_{5}$ (26.00), $\mathrm{T}_{6}(26.33), \mathrm{T}_{8}$ (25.67), and $\mathrm{T}_{11}$ (23.67) treatments. These findings are agreement with the observation of Arancon et al. (2006) who reported that application of vermicompost increased fruit number of strawberry and pepper. These findings are in agreement with

Table 2. Influence of organic and inorganic fertilizers on flowering and fruiting of papaya

\begin{tabular}{lcccc}
\hline Treatments & $\begin{array}{c}\text { Days to flower } \\
\text { initiation }\end{array}$ & $\begin{array}{c}\text { Total number of } \\
\text { flowers/ plant }\end{array}$ & $\begin{array}{c}\text { Days to fruit } \\
\text { setting }\end{array}$ & $\begin{array}{c}\text { Total number of } \\
\text { fruits/ plant }\end{array}$ \\
\hline $\mathrm{T}_{1}=$ Control & $92.33 \mathrm{a}$ & $33.33 \mathrm{f}$ & $151.33 \mathrm{a}$ & $23.33 \mathrm{~d}$ \\
$\mathrm{~T}_{2}=100 \% \mathrm{RDF}$ & $82.33 \mathrm{e}$ & $37.67 \mathrm{c}$ & $141.67 \mathrm{e}$ & $28.67 \mathrm{bc}$ \\
$\mathrm{T}_{3}=50 \% \mathrm{RDF}+50 \% \mathrm{MOC}$ & $89.33 \mathrm{~b}$ & $39.00 \mathrm{bc}$ & $146.67 \mathrm{c}$ & $26.00 \mathrm{~cd}$ \\
$\mathrm{~T}_{4}=50 \% \mathrm{RDF}+50 \% \mathrm{VER}$ & $83.33 \mathrm{de}$ & $37.33 \mathrm{~cd}$ & $142.67 \mathrm{e}$ & $27.00 \mathrm{c}$ \\
$\mathrm{T}_{5}=50 \% \mathrm{RDF}+50 \% \mathrm{PM}$ & $87.33 \mathrm{c}$ & $38.00 \mathrm{c}$ & $145.67 \mathrm{~cd}$ & $26.00 \mathrm{~cd}$ \\
$\mathrm{~T}_{6}=25 \% \mathrm{RDF}+75 \% \mathrm{MOC}$ & $88.00 \mathrm{bc}$ & $35.67 \mathrm{de}$ & $144.33 \mathrm{~d}$ & $26.33 \mathrm{~cd}$ \\
$\mathrm{~T}_{7}=25 \% \mathrm{RDF}+75 \% \mathrm{VER}$ & $84.33 \mathrm{~d}$ & $37.33 \mathrm{~cd}$ & $139.33 \mathrm{f}$ & $27.33 \mathrm{c}$ \\
$\mathrm{T}_{8}=25 \% \mathrm{RDF}+75 \% \mathrm{PM}$ & $87.33 \mathrm{c}$ & $38.33 \mathrm{bc}$ & $144.33 \mathrm{~d}$ & $25.67 \mathrm{~cd}$ \\
$\mathrm{~T}_{9}=100 \% \mathrm{MOC}$ & $83.67 \mathrm{de}$ & $35.67 \mathrm{de}$ & $148.33 \mathrm{~b}$ & $27.67 \mathrm{c}$ \\
$\mathrm{T}_{10}=100 \% \mathrm{VER}$ & $77.67 \mathrm{~g}$ & $41.67 \mathrm{a}$ & $131.00 \mathrm{~g}$ & $32.67 \mathrm{a}$ \\
$\mathrm{T}_{11}=100 \% \mathrm{PM}$ & $82.67 \mathrm{e}$ & $35.00 \mathrm{ef}$ & $143.67 \mathrm{de}$ & $23.67 \mathrm{~d}$ \\
$\mathrm{~T}_{12}=\mathrm{MOC}+\mathrm{VER}+\mathrm{PM}$ & $79.67 \mathrm{f}$ & $40.00 \mathrm{ab}$ & $131.67 \mathrm{~g}$ & $31.67 \mathrm{ab}$ \\
\hline $\mathrm{CV}(\%)$ & 1.00 & 2.94 & 0.42 & 7.14 \\
\hline $\mathrm{M}$ & & &
\end{tabular}

Means bearing same letter (s) in a column do not differ significantly at $5 \%$ level of probability. $\mathrm{RDP}=$ Recommended dose of fertilizer; $\mathrm{MOC}=$ Mustard oil cake; VER $=$ Vermicompost; $\mathrm{PM}=$ Poultry manure. 
the observation of Reddy et al. (2013) in papaya.

\section{Single fruit weight of papaya}

The influence of organic and inorganic fertilizers on single fruit weight was found significant (Table 3). The highest individual fruit weight was observed in treatment $\mathrm{T}_{10}$ $(742.00 \mathrm{~g})$ which was statistically similar to $\mathrm{T}_{12}(723.67 \mathrm{~g})$ and the lowest was observed in the control $\mathrm{T}_{1}(289.33 \mathrm{~g})$ treatment. Arancon et al. (2006) found that the application of vermicompost increased the fruit weight of strawberry and pepper. Vermicompost has growth promoting substances that normally increase the fruit size and shape. Yadav et al. (2011b) in papaya supported these findings.

\section{Fruit length}

In case of fruit length, a significant result was found in the application of different levels of organic and inorganic fertilizer treatments (Table 3). The highest fruit length was recorded in $\mathrm{T}_{10}(22.67 \mathrm{~cm})$ treatment which was closely followed by $\mathrm{T}_{12}(21.33 \mathrm{~cm})$ and the lowest was in the control $\mathrm{T}_{1}(9.90 \mathrm{~cm})$ which was statistically inferior to all other treatments. These findings are in agreement with Alidadi et al. (2014) who reported that the application of vermicompost leachates increased the length of tomato fruits. This findings are also agreement with the findings by Shijini (2010) in papaya.

\section{Fruit diameter}

The application of different levels of organic and inorganic fertilizers markedly influenced the fruit diameter (Table 3). The highest fruit diameter was found in $\mathrm{T}_{10}(34.50 \mathrm{~cm})$ treatment which was statistically superior to all other treatments. On the other hand, the lowest fruit diameter was found in the control

Table 3. Influence of organic and inorganic fertilizers on single fruit weight, fruit length, fruit diameter, pulp thickness and yield of papaya

\begin{tabular}{lcccccc}
\hline Treatments & $\begin{array}{c}\text { Single fruit } \\
\text { weight }(\mathrm{g})\end{array}$ & $\begin{array}{c}\text { Fruit length } \\
(\mathrm{cm})\end{array}$ & $\begin{array}{c}\text { Fruit } \\
\text { diameter } \\
(\mathrm{cm})\end{array}$ & $\begin{array}{c}\text { Pulp } \\
\text { thickness } \\
(\mathrm{cm})\end{array}$ & $\begin{array}{c}\text { Yield/ plant } \\
(\mathrm{kg})\end{array}$ & $\begin{array}{c}\text { Yield/ ha } \\
(\mathrm{MT})\end{array}$ \\
\hline $\mathrm{T}_{1}=$ Control & $289.33 \mathrm{~g}$ & $9.90 \mathrm{~g}$ & $24.83 \mathrm{f}$ & $1.94 \mathrm{e}$ & $6.84 \mathrm{~g}$ & $17.10 \mathrm{~h}$ \\
$\mathrm{~T}_{2}=100 \% \mathrm{RDF}$ & $642.33 \mathrm{~cd}$ & $17.00 \mathrm{~cd}$ & $27.33 \mathrm{de}$ & $2.73 \mathrm{~b}$ & $18.41 \mathrm{c}$ & $46.03 \mathrm{c}$ \\
$\mathrm{T}_{3}=50 \% \mathrm{RDF}+50 \% \mathrm{MOC}$ & $562.67 \mathrm{ef}$ & $14.60 \mathrm{def}$ & $26.00 \mathrm{ef}$ & $2.48 \mathrm{c}$ & $14.41 \mathrm{f}$ & $36.53 \mathrm{fg}$ \\
$\mathrm{T}_{4}=50 \% \mathrm{RDF}+50 \% \mathrm{VER}$ & $602.67 \mathrm{de}$ & $13.83 \mathrm{ef}$ & $25.33 \mathrm{f}$ & $2.65 \mathrm{~b}$ & $16.25 \mathrm{de}$ & $40.53 \mathrm{e}$ \\
$\mathrm{T}_{5}=50 \% \mathrm{RDF}+50 \% \mathrm{PM}$ & $635.67 \mathrm{~cd}$ & $14.90 \mathrm{def}$ & $26.33 \mathrm{ef}$ & $2.45 \mathrm{c}$ & $16.51 \mathrm{de}$ & $41.28 \mathrm{de}$ \\
$\mathrm{T}_{6}=25 \% \mathrm{RDF}+75 \% \mathrm{MOC}$ & $551.00 \mathrm{ef}$ & $12.90 \mathrm{f}$ & $28.00 \mathrm{~cd}$ & $2.48 \mathrm{c}$ & $14.51 \mathrm{f}$ & $36.28 \mathrm{fg}$ \\
$\mathrm{T}_{7}=25 \% \mathrm{RDF}+75 \% \mathrm{VER}$ & $678.00 \mathrm{bc}$ & $18.67 \mathrm{bc}$ & $29.00 \mathrm{c}$ & $2.73 \mathrm{ab}$ & $18.53 \mathrm{c}$ & $46.33 \mathrm{c}$ \\
$\mathrm{T}_{8}=25 \% \mathrm{RDF}+75 \% \mathrm{PM}$ & $671.33 \mathrm{bc}$ & $16.00 \mathrm{cde}$ & $26.00 \mathrm{ef}$ & $2.41 \mathrm{c}$ & $17.22 \mathrm{~cd}$ & $43.50 \mathrm{~d}$ \\
$\mathrm{~T}_{9}=100 \% \mathrm{MOC}$ & $536.00 \mathrm{f}$ & $13.33 \mathrm{ef}$ & $26.00 \mathrm{ef}$ & $2.10 \mathrm{~d}$ & $14.84 \mathrm{ef}$ & $37.07 \mathrm{f}$ \\
$\mathrm{T}_{10}=100 \% \mathrm{VER}$ & $742.00 \mathrm{a}$ & $22.67 \mathrm{a}$ & $34.50 \mathrm{a}$ & $2.93 \mathrm{a}$ & $24.23 \mathrm{a}$ & $60.06 \mathrm{a}$ \\
$\mathrm{T}_{11}=100 \% \mathrm{PM}$ & $595.33 \mathrm{def}$ & $16.67 \mathrm{~cd}$ & $26.33 \mathrm{ef}$ & $2.38 \mathrm{c}$ & $13.87 \mathrm{f}$ & $34.70 \mathrm{~g}$ \\
$\mathrm{~T}_{12}=$ MOC $+\mathrm{VER}+\mathrm{PM}$ & $723.67 \mathrm{ab}$ & $21.33 \mathrm{ab}$ & $31.00 \mathrm{~b}$ & $2.77 \mathrm{ab}$ & $22.91 \mathrm{~b}$ & $57.27 \mathrm{~b}$ \\
\hline $\mathrm{CV}(\%)$ & 5.98 & 9.96 & 3.45 & 3.47 & 6.02 & 3.09 \\
\hline
\end{tabular}

Means bearing same letter (s) in a column do not differ significantly at $5 \%$ level of probability. $\mathrm{RDP}=$ Recommended dose of fertilizer; $\mathrm{MOC}=$ Mustard oil cake; VER $=$ Vermicompost; $\mathrm{PM}=$ Poultry manure. 
$\mathrm{T}_{1}(24.83 \mathrm{~cm})$ which was statistically similar to $\mathrm{T}_{3}(26.00 \mathrm{~cm}), \mathrm{T}_{4}(25.33 \mathrm{~cm}), \mathrm{T}_{5}(26.33 \mathrm{~cm})$, $\mathrm{T}_{8}(26.00 \mathrm{~cm}), \mathrm{T}_{9}(26.00 \mathrm{~cm})$, and $\mathrm{T}_{11}(26.33$ $\mathrm{cm})$. The similar result was also obtained by Nath (2001) who reported an improved fruit diameter and yield of papaya with the application of organic fertilizers. These findings are also in supported by the findings of Ram and Rajput (1998) in guava and Dutta et al. (2008) in papaya.

\section{Pulp thickness}

Pulp thickness is one of the important characters determining the quality of papaya (Table 3). The maximum pulp thickness was observed in $\mathrm{T}_{10}(2.93 \mathrm{~cm})$ treatment which was statistically similar to $T_{12}(2.77 \mathrm{~cm})$ and $\mathrm{T}_{7}(2.73 \mathrm{~cm})$. On the other hand, the lowest pulp thickness was observed in the plant under control $\mathrm{T}_{1}(1.94 \mathrm{~cm})$. Singh et al. (2008a) reported in papaya also the same opinion and agreed with the present findings.

\section{Yield per plant}

Fruit yield varied significantly due to the treatments. Organic sources of nutrients produced markedly better yields than that of the inorganic fertilizers in the control treatment (Table 3). The maximum fruit yield per plant was recorded in treatment $T_{10}(24.23$ $\mathrm{kg}$ ) which was statistically dissimilar from all other treatments. The lowest yield per plant was found in the control $\mathrm{T}_{1}(6.84 \mathrm{~kg})$ which was statistically inferior to other treatments. These present findings are supported by the findings of Yadav et al. (2011b)

\section{Yield per hectare}

Due to the influence of organic and inorganic fertilizer on yield of papaya per hectare varied significantly ranging from $17.10 \mathrm{MT}$ to $60.06 \mathrm{MT}$ (Table 3). In the application of vermicompost equivalent to $100 \%$ recommended dose of nitrogen (RDN) $\mathrm{T}_{10}$ (60.06 MT/ha) treatment gave significantly higher fruit yield/ ha which was statistically dissimilar from other treatments. The lower yield/ha was recorded in the control $\mathrm{T}_{1}(17.10$ $\mathrm{MT} / \mathrm{ha}$ ) which was statistically inferior to all other treatments. The application of Vermicompost is the effective source for growth and yield of strawberry (Rahman et al., 2018). These findings are in agreement with the findings of Yadav et al. (2011b) in papaya.

\section{Dry matter}

The dry meter is the most important parameter in papaya. There were significant differences in different levels of fertilizer treatment (Table 4). Dry matter increased with increasing the rate of leaf area and canopy which increase the photosynthesis activity. The maximum amount of dry matter content was found in $\mathrm{T}_{10}(4.37 \%)$ treatment which was statistically similar by $\mathrm{T}_{12}(4.33 \%)$. The minimum amount of dry weight was found in the control $\mathrm{T}_{1}$ $(2.57 \%)$ treatment which was statistically inferior to all other treatments. Singh et al. (2008) reported that there was a significant increase in the plant canopy, leaf area, and dry matter in strawberry with the application of vermicompost which agree with these present findings.

\section{Total soluble solids (TSS) content}

Total soluble solids is an important quality determining character in papaya. There were significant differences in TSS per plant to different levels of fertilizers utilization from different treatments (Table 4). The TSS (\%) showed an increased with the increased amount of different kinds of organic fertilizer along 
Table 4. Influence of organic and inorganic fertilizers on dry matter, TSS and sugar content of papaya

\begin{tabular}{lccccc}
\hline Treatment combination & $\begin{array}{c}\text { Dry matter } \\
(\%)\end{array}$ & $\begin{array}{c}\text { TSS } \\
(\%)\end{array}$ & $\begin{array}{c}\text { Total sugar } \\
(\mathrm{g} / 100 \mathrm{~g})\end{array}$ & $\begin{array}{c}\text { Reducing } \\
\text { sugar }(\mathrm{g} / 100 \mathrm{~g})\end{array}$ & $\begin{array}{c}\text { Non-reducing } \\
(\mathrm{g} / 100 \mathrm{~g})\end{array}$ \\
\hline $\mathrm{T}_{1}=$ Control & $2.57 \mathrm{~h}$ & $8.43 \mathrm{~h}$ & $5.29 \mathrm{~h}$ & $2.92 \mathrm{~g}$ & $2.37 \mathrm{~d}$ \\
$\mathrm{~T}_{2}=100 \% \mathrm{RDF}$ & $3.70 \mathrm{~b}$ & $15.17 \mathrm{~d}$ & $7.13 \mathrm{bc}$ & $4.17 \mathrm{c}$ & $2.96 \mathrm{bc}$ \\
$\mathrm{T}_{3}=50 \% \mathrm{RDF}+50 \% \mathrm{MOC}$ & $3.36 \mathrm{efg}$ & $10.30 \mathrm{~g}$ & $5.77 \mathrm{fgh}$ & $3.54 \mathrm{de}$ & $2.23 \mathrm{~d}$ \\
$\mathrm{~T}_{4}=50 \% \mathrm{RDF}+50 \% \mathrm{VER}$ & $3.56 \mathrm{~cd}$ & $14.70 \mathrm{~d}$ & $6.77 \mathrm{~cd}$ & $3.78 \mathrm{~cd}$ & $2.99 \mathrm{bc}$ \\
$\mathrm{T}_{5}=50 \% \mathrm{RDF}+50 \% \mathrm{PM}$ & $3.33 \mathrm{fg}$ & $11.83 \mathrm{f}$ & $5.50 \mathrm{gh}$ & $3.13 \mathrm{fg}$ & $2.37 \mathrm{~d}$ \\
$\mathrm{~T}_{6}=25 \% \mathrm{RDF}+75 \% \mathrm{MOC}$ & $3.46 \mathrm{de}$ & $11.40 \mathrm{f}$ & $5.73 \mathrm{fgh}$ & $3.00 \mathrm{fg}$ & $2.73 \mathrm{c}$ \\
$\mathrm{T}_{7}=25 \% \mathrm{RDF}+75 \% \mathrm{VER}$ & $3.63 \mathrm{bc}$ & $16.40 \mathrm{c}$ & $7.67 \mathrm{~b}$ & $4.67 \mathrm{~b}$ & $3.00 \mathrm{~b}$ \\
$\mathrm{~T}_{8}=25 \% \mathrm{RDF}+75 \%$ PM & $3.60 \mathrm{bc}$ & $14.93 \mathrm{~d}$ & $6.23 \mathrm{def}$ & $3.80 \mathrm{~cd}$ & $2.43 \mathrm{~d}$ \\
$\mathrm{~T}_{9}=100 \% \mathrm{MOC}$ & $3.26 \mathrm{~g}$ & $13.20 \mathrm{e}$ & $6.10 \mathrm{efg}$ & $3.33 \mathrm{ef}$ & $2.77 \mathrm{bc}$ \\
$\mathrm{T}_{10}=100 \% \mathrm{VER}$ & $4.37 \mathrm{a}$ & $18.17 \mathrm{a}$ & $9.43 \mathrm{a}$ & $6.34 \mathrm{a}$ & $3.09 \mathrm{ab}$ \\
$\mathrm{T}_{11}=100 \%$ PM & $3.43 \mathrm{ef}$ & $13.80 \mathrm{e}$ & $6.43 \mathrm{de}$ & $3.70 \mathrm{de}$ & $2.73 \mathrm{c}$ \\
$\mathrm{T}_{12}=$ MOC+ VER+ PM & $4.33 \mathrm{a}$ & $17.30 \mathrm{~b}$ & $9.10 \mathrm{a}$ & $5.17 \mathrm{ab}$ & $3.93 \mathrm{a}$ \\
\hline $\mathrm{CV}(\%)$ & 2.19 & 3.47 & 5.41 & 5.99 & 4.81 \\
\hline
\end{tabular}

Means bearing same letter (s) in a column do not differ significantly at $5 \%$ level of probability. $\mathrm{RDP}=$ Recommended dose of fertilizer; $\mathrm{MOC}=$ Mustard oil cake; VER = Vermicompost; PM $=$ Poultry manure; TSS $=$ Total Soluable sdids

with the control. The maximum amount of TSS content was found in $\mathrm{T}_{10}(18.17 \%)$ which was statistically similar to $\mathrm{T}_{12}(17.30 \%)$. The lowest amount of TSS content was found in the fruit of the plant under control $\mathrm{T}_{1}(8.43 \%)$ treatment. These findings are in agreement with the observation of Kirad et al. (2010) who reported that the TSS level was to be increased by the application of vermicompost with decreasing level of chemical fertilizers.

\section{Total sugar}

Significant variation was found in total sugar content to different doses of organic and inorganic fertilizers treatment (Table 4). The maximum amount of total sugar was found in $\mathrm{T}_{10}(9.43 \mathrm{~g} / 100 \mathrm{~g})$ treatment which was statistically similar to $T_{12}(9.10 \mathrm{~g} / 100 \mathrm{~g})$. The minimum amount of total sugar was found in the control $\mathrm{T}_{1}(5.29 \mathrm{~g} / 100 \mathrm{~g})$ which was statistically similar to $\mathrm{T}_{3}(5.77 \mathrm{~g} / 100 \mathrm{~g}), \mathrm{T}_{5}(5.50$ $\mathrm{g} / 100 \mathrm{~g})$, and $\mathrm{T}_{6}(5.73 \mathrm{~g} / 100 \mathrm{~g})$. Vermicompost makes the micronutrients in readily available form for plant and due to the availability of these nutrients sweetness of papaya fruits was increased. Kirad et al. (2009) in strawberry and Ravishankar and Karunakaran (2008) in papaya supported these present findings.

\section{Reducing sugar}

In case of reducing sugar, significant variation was found due to the different treatments (Table 4). Organic sources of nutrients produced markedly better result than that of the control treatment. The maximum amount of reducing sugar was observed in $\mathrm{T}_{10}(6.34$ $\mathrm{g} / 100 \mathrm{~g}$ ) treatment which was closely followed by $\mathrm{T}_{12}(5.17 \mathrm{~g} / 100 \mathrm{~g})$. The lowest amount of reducing sugar was found in control $\mathrm{T}_{1}(2.92$ $\mathrm{g} / 100 \mathrm{~g}$ ) which was statistically similar to $\mathrm{T}_{5}$ $(3.13 \mathrm{~g} / 100 \mathrm{~g})$ and $\mathrm{T}_{6}(3.00 \mathrm{~g} / 100 \mathrm{~g})$ treatment. These findings are in conformity with the 
findings of Ravishankar et al. (2008) who stated that the application of organic fertilizers which improved the reducing sugar and other quality of papaya.

\section{Non-reducing sugar}

The non-reducing sugar content was statistically significant to different level of treatment (Table 4). The maximal amount of non-reducing sugar was found in $\mathrm{T}_{12}$ (3.93 $\mathrm{g} / 100 \mathrm{~g}$ ) which was statistically similar to $\mathrm{T}_{10}$ $(3.09 \mathrm{~g} / 100 \mathrm{~g})$. The minimum amount of nonreducing sugar was found in $\mathrm{T}_{3}(2.23 \mathrm{~g} / 100 \mathrm{~g})$ treatment which was statistically similar to $\mathrm{T}_{1}(2.37 \mathrm{~g} / 100 \mathrm{~g}), \mathrm{T}_{5}(2.37 \mathrm{~g} / 100 \mathrm{~g})$, and $\mathrm{T}_{8}$ $(2.43 \mathrm{~g} / 100 \mathrm{~g})$ treatment. Eda et al. (2018) also reported similar findings.

\section{Ascorbic acid}

The highest amount of ascorbic acid content was found in $\mathrm{T}_{7}(24.99 \mathrm{mg} / 100 \mathrm{~g})$ treatment which was closely followed by $\mathrm{T}_{2}(24.45$ $\mathrm{mg} / 100 \mathrm{~g}), \mathrm{T}_{6}(24.22 \mathrm{mg} / 100 \mathrm{~g}), \mathrm{T}_{10}(24.67$ $\mathrm{mg} / 100 \mathrm{~g})$ and $\mathrm{T}_{12}(24.33 \mathrm{mg} / 100 \mathrm{~g})$. The lowest amount of ascorbic acid was found in $\mathrm{T}_{11}(22.00 \mathrm{mg} / 100 \mathrm{~g})$ treatment which was statistically similar to $\mathrm{T}_{1}(22.67 \mathrm{mg} / 100 \mathrm{~g})$ and $\mathrm{T}_{5}(22.60 \mathrm{mg} / 100 \mathrm{~g})$. Similar results was obtained by Yadav et al. (2011a) in papaya.

\section{$\beta$-Carotene}

The highest $\beta$-Carotene content was observed in $\mathrm{T}_{10}(0.24 \mathrm{mg} / 100 \mathrm{~g})$ treatment which was closely related to $\mathrm{T}_{12}(0.23 \mathrm{mg} / 100 \mathrm{~g})$ and $\mathrm{T}_{7}(0.23 \mathrm{mg} / 100 \mathrm{~g})$ treatments. On the other hand, the lowest amount of $\beta$-Carotene content was observed in treatment $T_{5}(0.16 \mathrm{mg} / 100 \mathrm{~g})$ treatment which was statistically similar with $\mathrm{T}_{1}(0.17 \mathrm{mg} / 100 \mathrm{~g}), \mathrm{T}_{3}(0.18 \mathrm{mg} / 100 \mathrm{~g})$, $\mathrm{T}_{4}(0.18 \mathrm{mg} / 100 \mathrm{~g})$ and $\mathrm{T}_{9}(0.18 \mathrm{mg} / 100 \mathrm{~g})$. The $\beta$-Carotene content was more in fruits of plants applied with organic fertilizer might be due to continuous supply of both macro and micro nutrients to the plants. These results were in harmony with the earlier findings of Singh et al. (2008a) in papaya.

\section{Calcium (Ca)}

Significant variation was found in calcium content to different doses of organic and inorganic fertilizers treatment (Table 5). The maximum amount of calcium content was found in $\mathrm{T}_{10}(0.39 \%)$ treatment which was statistically similar to $\mathrm{T}_{12}(0.37 \%)$. The lowest amount of calcium was found in the control $\mathrm{T}_{1}$ $(0.27 \%)$ which was statistically similar to $T_{5}$ $(0.29 \%)$ treatment. Calcium concentration was maximum in papaya fruit treated with organic fertilizers. These results are in conformity with the findings of Ray et al. (2008) reported that significant increase in quality content of papaya fruits due to the application of organic fertilizers.

\section{Magnesium (Mg)}

Different variation was found in magnesium content to different treatments. It varied from 0.16 to $0.33 \%$ (Table 5 ). The plants obtained from $\mathrm{T}_{10}(0.33 \%)$ treatment had significantly maximum magnesium content. The minimum amount of magnesium was found in the control $\mathrm{T}_{1}(0.16 \%)$ which was statistically similar to $\mathrm{T}_{3}(0.19 \%)$ and $\mathrm{T}_{6}(0.18 \%)$ treatments. These result are agreed with the findings of Verma and Kaushal (2014).

\section{Potassium (K)}

Potassium content was also significantly different among treatment. The maximum amount of potassium was found in $\mathrm{T}_{10}(2.08 \%)$ which was statistically similar to $\mathrm{T}_{12}(2.03 \%)$ (Table 5). The minimum amount of potassium was found in control $\mathrm{T}_{1}(1.78 \%)$ which was statistically identical with $\mathrm{T}_{8}(1.85 \%)$. Pant et 
Table 5. Influence of organic and inorganic fertilizers on ascorbic acid, $\beta$-Carotene, calcium, magnesium and potassium of papaya

\begin{tabular}{lccccc}
\hline Treatments & $\begin{array}{c}\text { Ascorbic acid } \\
(\mathrm{mg} / 100 \mathrm{~g})\end{array}$ & $\begin{array}{c}\beta \text {-Carotene } \\
\text { content }(\mathrm{mg} / 100 \mathrm{~g})\end{array}$ & Calcium (\%) & Magnesium (\%) & $\begin{array}{c}\text { Potassium } \\
(\%)\end{array}$ \\
\hline $\mathrm{T}_{1}=$ Control & $22.67 \mathrm{de}$ & $0.17 \mathrm{ef}$ & $0.27 \mathrm{~h}$ & $0.16 \mathrm{f}$ & $1.78 \mathrm{~d}$ \\
$\mathrm{~T}_{2}=100 \% \mathrm{RDF}$ & $24.45 \mathrm{ab}$ & $0.21 \mathrm{bc}$ & $0.34 \mathrm{cde}$ & $0.27 \mathrm{~b}$ & $1.96 \mathrm{bc}$ \\
$\mathrm{T}_{3}=50 \% \mathrm{RDF}+50 \% \mathrm{MOC}$ & $23.67 \mathrm{bcd}$ & $0.18 \mathrm{def}$ & $0.31 \mathrm{fg}$ & $0.19 \mathrm{ef}$ & $1.90 \mathrm{c}$ \\
$\mathrm{T}_{4}=50 \% \mathrm{RDF}+50 \% \mathrm{VER}$ & $23.51 \mathrm{bcd}$ & $0.18 \mathrm{ef}$ & $0.35 \mathrm{bcd}$ & $0.24 \mathrm{~cd}$ & $1.93 \mathrm{bc}$ \\
$\mathrm{T}_{5}=50 \% \mathrm{RDF}+50 \% \mathrm{PM}$ & $22.60 \mathrm{de}$ & $0.16 \mathrm{f}$ & $0.29 \mathrm{gh}$ & $0.22 \mathrm{de}$ & $1.92 \mathrm{bc}$ \\
$\mathrm{T}_{6}=25 \% \mathrm{RDF}+75 \% \mathrm{MOC}$ & $24.22 \mathrm{abc}$ & $0.19 \mathrm{cde}$ & $0.33 \mathrm{cdef}$ & $0.18 \mathrm{f}$ & $1.92 \mathrm{bc}$ \\
$\mathrm{T}_{7}=25 \% \mathrm{RDF}+75 \% \mathrm{VER}$ & $24.99 \mathrm{a}$ & $0.23 \mathrm{ab}$ & $0.36 \mathrm{bc}$ & $0.26 \mathrm{bc}$ & $1.92 \mathrm{bc}$ \\
$\mathrm{T}_{8}=25 \% \mathrm{RDF}+75 \% \mathrm{PM}$ & $23.67 \mathrm{bcd}$ & $0.21 \mathrm{bcd}$ & $0.32 \mathrm{efg}$ & $0.23 \mathrm{~cd}$ & $1.85 \mathrm{~cd}$ \\
$\mathrm{~T}_{9}=100 \% \mathrm{MOC}$ & $23.22 \mathrm{~cd}$ & $0.18 \mathrm{def}$ & $0.33 \mathrm{def}$ & $0.24 \mathrm{~cd}$ & $1.91 \mathrm{bc}$ \\
$\mathrm{T}_{10}=100 \% \mathrm{VER}$ & $24.67 \mathrm{ab}$ & $0.24 \mathrm{a}$ & $0.39 \mathrm{a}$ & $0.33 \mathrm{a}$ & $2.08 \mathrm{a}$ \\
$\mathrm{T}_{11}=100 \%$ PM & $22.00 \mathrm{e}$ & $0.19 \mathrm{cde}$ & $0.34 \mathrm{cdef}$ & $0.25 \mathrm{bc}$ & $1.90 \mathrm{c}$ \\
$\mathrm{T}_{12}=\mathrm{MOC}+\mathrm{VER}+\mathrm{PM}$ & $24.33 \mathrm{abc}$ & $0.23 \mathrm{ab}$ & $0.37 \mathrm{ab}$ & $0.28 \mathrm{~b}$ & $2.03 \mathrm{ab}$ \\
\hline $\mathrm{CV}(\%)$ & 3.03 & 7.19 & 5.06 & 7.00 & 3.57 \\
\hline
\end{tabular}

Means bearing same letter (s) in a column do not differ significantly at $5 \%$ level of probability.

$\mathrm{RDP}=$ Recommended dose of fertilizer; $\mathrm{MOC}=$ Mustard oil cake; VER= Vermicompost; PM = Poultry manure.

al. (2009) reported that in pak choi, the total $\mathrm{P}$ and $\mathrm{K}$ contents per plant were also higher in vermicompost tea-treated plants compared with control.

\section{Conclusions}

In conclusion, the present study reports that the establishment of an effective application of organic fertilizers as an alternative source of fertilizers for more production of papaya. Application of vermicopmost also showed the significant results on growth, yield and physiochemical properties. The plant produced maximum growth and yield of papaya due to application of $12.5 \mathrm{~kg}$ vermicompost/plant (treatment $\mathrm{T}_{10}$ ).

\section{Reference}

Akinyemi, S. and M. O. Akanda. 2008. Effect of organic and inorganic fertilizers on growth and yield of pawpaw (Carica papaya L.). Interciencia. 29: 274-270.

Alidadi, H., A. R. Saffari, D. Ketabi, R. Peiravi and A. Hosseinzadeh. 2014. Comparison of vermicompost and cow manure efficiency on the growth and yield of tomato plant. Health Scope. 3(4): 146-61.

AOAC (Association of Official Agricultural Chemist). 1965. Official Methods of Analysis, AOAC, Washington DC.

Arancon, N. Q., C. A. Edwards and P. Bierman. 2006. Influences of vermicomposts on field strawberries: Part 2. Effects on soil microbiological and chemical properties. Bior. Tech. 97(6): 831-840. 
BARC (Bangladesh Agricultural Research Council). 2012. Fertilizer Recommendation Guide. Pp. 84-264. Bangladesh Agricultural Research Council, Farmgate, Dhaka, 1215.

Chowdhury, M. G. F., M. N. Islam, M. S. Islam, A. F. M. T. Islam and M. S. Hossain. 2008. Study on preparation and shelf-life of mixed juice based on wood apple and papaya. J. Soil Nature. 2(3): 50-60.

Dutta, P., S. Kundu and S. Chatterjee. 2008. Effect of bio-fertilizers on homestead fruit production of papaya cv. Ranchi. In: II International Symposium on Papaya. 851: 385- 388.

Eda, R., D. V. Swami, B. P. Kumar, T. K. Patro and D. R. S. Suneetha. 2018. Effect of organic manures on fruit quality of papaya cv. Arka prabhat. Int. J. Curr. Microbiol. App. Sci. 7(12): 3605-3610.

El Moussaoui, A., M. Nijs, C. Paul, R. Wintjens, J. Vincentelli, M. Azarkan and Y. Looze. 2001. Revisiting the enzymes stored in the laticifers of Carica papaya in the context of their possible participation in the plant defense mechanism. Cell. Mol. Life Sci. 58(4): 556-570.

El-Shakweer, M. H. A., E. A. El-Sayad, M. S. Ewees. 1998. Soil and Plant analysis as a guide for interpretation of the improvement efficiency of organic conditioners added to different soils in Egypt. Commun. Soil Sci. Plant Anal. 29(11-14): 2067-2088.

Joshi, R. and A. P. Vig. 2010. Effect of vermicomposting on growth, yield and quality of tomato (Lycopersicum esculentum L). African J. Basic. Appl. Sci. 2(3-4): 117-123.

Khan, F., F. A. Banday, S. Narayan, F. U. Khan and S. A. Bhat. 2016. Use of models as non-destructive method for leaf area estimation in horticultural crops. IRAInternat. J. Appl. Sci. 4(1): 19.
Kirad, K. S., S. Barche and D. B. Singh. 2009. Response of integrated nutrient management in strawberry (Fragaria $\times$ ananassa D.). Acta Hort. 842: 653-656.

Kirad, K. S., S. Barche and D. B. Singh. 2010. Integrated nutrient management in papaya (Carica papaya L.) cv. Surya. In II International Symposium on Papaya. 851: 377-380.

Krishna, V. N. P. S., M. L. N. Reddy, A. V. D. D. Rao, K. T. Venkataramana and P. Sudhakar. 2018. Effect of nutritional substitution on growth, flowering and fruit yield of papaya cv. Arka Prabhat. Plant Archiv. 18(1): 1000-1004.

Mamta, D. D., S. B. Gupta and S. Deole. 2017. Effect of integrated nutrient management on growth and nutrient uptake in papaya (Carica papaya L.) At nursery level. $J$. Pharmacog. Phytochem. 6(5): 522-527.

Maritus, C. H. T. and P. L. G. Vleic. 2001. The management of organic matter in tropical soils. What are the priorities? Nutr. Cycling Agroecosyst. 61: 1-6.

Nagata, M. and I. Yamashita. 1992. Simple method for simultaneous determination of chlorophyll and carotenoids in tomato fruit. Nippon Shokuhin Kogyo Gakkaishi. 39(10): 925-928.

Nath, S. 2001. Studies on the efficiency of different bio-fertilizers in the integrated nutrient management of papaya (Carica papaya L.). Doctoral Dissertation, Ph. D. Thesis.

Ojeniyi, S. O. 2000. Effect of goat manure on soil nutrients and okra yield in a rain forest area of Nigeria. Appl. Tropical Agric. 5: 20-23.

Pant, A. P., T. J. Radovich, N. V. Hue, S. T. Talcott and K. A. Krenek. 2009. Vermicompost extracts influence growth, mineral nutrients, phytonutrients and antioxidant activity in pak choi (Brassica rapa cv. Bonsai, Chinensis group) grown under vermicompost and chemical fertiliser. $J$. Sci. Food Agric. 89(14): 2383-2392. 
Rahman, M. M., M. N. Islam, M. Z. K. Roni, O. Gani and A. F. M. J. Uddin. 2018. Vermicompost and mustard oil cake as an alternative fertilizer for strawberry production. Int. J. Bus. Soc. Sci. Res. 6(3): 78-84.

Rajamanickam, C., S. Balasubramanyan and S. Natarajan. 2008. Studies on nursery management in papaya (Carica papaya L.) Var. $\mathrm{CO}_{2}$. In II International Symposium on Papaya. 851: 307-312.

Ram, R. A. and M. S. Rajput. 1998. Effect of organic and bio-fertilizers on growth, yield and fruit quality of guava cv. Allahabad Safeda. Inter. J. Mendel. 15(12): 168-169.

Ravishankar, H. and G. Karunakaran. 2008. Performance of coorg honey dew papaya under organic farming regimes in the hill zone of karnataka. In: II International Symposium on Papaya. 851: 259-262.

Ravishankar, H., G. Karunakaran and S. Hazarika. 2008. Nutrient availability and biochemical properties in soil as influenced by organic farming of papaya under Coorg region of Karnataka. In: II International Symposium on Papaya. 851: 419-424.

Ray, P. K., A. K. Singh and A. Kumar. 2008. Performance of Pusa Delicious papaya under organic farming. Indian $J$. Hort. 65(1): 100-101.

Reddy, Y. T. N., R. M. Kurian, A. N. Ganeshamurthy and P. Pannerselvam. 2010. Effect of organic nutrition practices on papaya (cv. Surya) fruit yield, quality and soil health. J. Hort. Sci. 5(2): 124127.

Reddy, Y. T. N., R. M. Kurian, A. N. Ganeshamurthy, P. Pannersalvam and S. R. Prasad. 2014. Effect of organic practices on growth, fruit yield, quality and soil health of papaya cv. Arka Prabhat. Indian Hort. J. 4(1): 9-13.
Reddy, Y. T. N., R. M. Kurian, A. N. Ganeshamurthy, P. Pannerselvam and S. S. Prasad. 2013. Influence of organic practices on growth and fruit yield in papaya cv. Surya J. Hort. Sci. 8(2): 246-248.

Reddy, Y. T. N., S. S. Prasad, R. M. Kurian, A. N. Ganeshamurthy and P. Pannerselvam. 2012. Effect of organic practices on fruit quality in papaya cv. Surya. J. Hort. Sci. 7(1): 88-90.

Shijini, E. M. 2010. Response of papaya to organic manures, plant growth promoting microorganisms and mulching. Doctoral Dissertation, Department of Pomology and Floriculture, College of Horticulture, Vellanikkara.

Sindoni, V. M., L. P. R. Hidalgo, L. Marcano and F. Salcedo. 2009. Effect of vermicompost as an organic amendment on the initial growth of papaya (Carica papaya L). cv.'Maradol Amarilla'plants. Revista Cientifica UDO Agrícola. 9(2): 322-326.

Singh, K., S. Barche and D. B. Singh. 2008a. Integrated nutrient management in papaya (Carica papaya L.) cv. Surya. In II International Symposium on Papaya. 851. 377-380.

Singh, R., R. R. Sharma, S. Kumar, R. K. Gupta and R. T. Patil. 2008. Vermicompost substitution influences growth, physiological disorders, fruit yield and quality of strawberry (Fragaria x ananassa Duch.). Biores. Technol. 99(17): 8507-8511.

Singh, S. P., S. Kumar, S. V. Mathan, M. S. Tomar, R. K. Singh, P. K. Verma, A. Kumar, S. Kumar, R. P. Singh and A. Acharya. 2020. Therapeutic application of Carica papaya leaf extract in the management of human diseases. DARU J. Pharm. Sci. 28: 735-744.

Singh, V. K., V. Kumar and A. Bahuguna. 2012. Impact of fertilizer on yield of papaya cv. Pusa Dwarf under Indo Gangetic condition. J. Crop Weed. 8(2): 74-76. 
Somogyi, M. 1952. Notes on sugar determination. J. Biol. Chem. 195: 19- 23.

Taleshi, K., A. Shokoh-far, M. Rafiee, G. Noormahamadi and T. Sakinejhad. 2011. Effect of vermicompost and nitrogen levels on yield and yield component of safflower (Carthamus tinctorius L.) under late season drought stress. Intl. J. Agron. Plant Prod. 2(1): 15-22

Tomati, U., A. Grappelli and E. Galli. 1988. The hormone-like effect of earthworm casts on plant growth. Biol. Fertil. Soil. 5(4): 288-294.

Verma, K. S. and V. S. Kaushal. 2014. Nutritive assessment of different plant parts of Carica papaya Linn of Jabalpur region. $J$. Nat. Prod. Plant Resour. 4(1): 52-56.
Yadav, P. K., A. L. Yadav, A. S. Yadav and H. C. Yadav. 2011a. Effect of integrated nutrient nourishment on vegetative growth and physico-chemical attributes of papaya (Carica papaya L.) fruit cv. pusa dwarf. Plant Archiv. 11(1): 327-329.

Yadav, P. K., A. L. Yadav, A. S. Yadav, H. C. Yadav and Y. P. Singh. 2011b. Effect of integrated nutrient nourishment on yield attributes and economics of papaya (Carica papaya L.) cv. pusa dwarf. Plant Archiv. 11(1): 307-309.

Yadava, U. L., J. A. Burris and D. McCrary. 1990. Papaya: a potential annual crop under middle Georgia conditions. Pp. 364-366. In Advances in new crops. Proceedings of the first national symposium' New crops: research, development, economics', Indianapolis, Indiana, USA. 
